Proceeding Paper

\title{
Supply Potential and Annual Availability of Timber and Forest Biomass Resources for Energy Considering Inter-Prefectural Trade in Tohoku Region of Japan ${ }^{+}$
}

\author{
Yusuke Matsuoka ${ }^{1}$, Hiroaki Shirasawa ${ }^{2}$, Uichi Hayashi ${ }^{1}$ and Kazuhiro Aruga ${ }^{1, *}$
}

Citation: Matsuoka, Y.; Shirasawa, H.; Hayashi, U.; Aruga, K. Supply Potential and Annual Availability of Timber and Forest Biomass Resources for Energy Considering Inter-Prefectural Trade in Tohoku Region of Japan. Environ. Sci. Proc. 2021, 3, 40. https://doi.org/10.3390/ IECF2020-08025

Academic Editors: Angela Lo Monaco, Cate Macinnis-Ng and Om P. Rajora

Published: 12 November 2020

Publisher's Note: MDPI stays neutral with regard to jurisdictional claims in published maps and institutional affiliations.

Copyright: $@ 2020$ by the authors. Licensee MDPI, Basel, Switzerland. This article is an open access article distributed under the terms and conditions of the Creative Commons Attribution (CC BY) license (http://creativecommons.org/licenses/by/4.0/)
1 Department of Forest Science, Utsunomiya University, Tochigi 321-8505, Japan; mc196952@cc.utsunomiya-u.ac.jp (Y.M.); uichi@cc.utsunomiya-u.ac.jp (U.H.)

2 Department of Forest Engineering, Forestry and Forest Products Research Institute, Ibaraki 305-8687, Japan; shirasawa@ffpri.affrc.go.jp

* Correspondence: aruga@cc.utsunomiya-u.ac.jp

† Presented at the 1st International Electronic Conference on Forests - Forests for a Better Future: Sustainability, Innovation, Interdisciplinarity, 15-30 November 2020; Available online: https://iecf2020.sciforum.net.

\begin{abstract}
To promote sustainable timber and forest biomass utilization, this study estimated technically feasible and economically viable availability considering forest regenerations. This study focuses on five prefectures, namely, Aomori, Iwate, Miyagi, Akita, and Yamagata, and considers the trade between these prefectures. The data used in this study include forest registration (tree species and site index) and GIS data (information on roads and subcompartment layers) from the prefectures for private and communal forests. Additionally, this study includes GIS data (subcompartment layers, including tree species) from the Forestry Agency of Japan for national forests as well as 10-m-grid digital elevation models (DEMs) from the Geographical Survey Institute. As a result, supply potentials of timber and forest biomass resources were estimated at 11,388,960 $\mathrm{m}^{3} /$ year and $2,277,792 \mathrm{~m}^{3} /$ year, respectively. Then, those availabilities were estimated at 1,631,624 $\mathrm{m}^{3} /$ year and $326,325 \mathrm{~m}^{3} /$ year. Therefore, the rate of availabilities to supply potentials was $14.3 \%$. Since timber production, and wood chip usage from thinned woods and logging residues in 2018 were 4,667,000 $\mathrm{m}^{3} /$ year and $889,600 \mathrm{~m}^{3} /$ year, respectively, the rates of timber and forest biomass resource availabilities to those values were $35.0 \%$ and $36.7 \%$, respectively. Furthermore, the demand was estimated at $951,740 \mathrm{~m}^{3} /$ year from $100,000 \mathrm{~m}^{3} /$ year with the generation capacity of $5 \mathrm{MW}$. The rate of forest biomass resource availability versus the demand was $34.2 \%$. The rates were increased to $64.1 \%$ with an additional regeneration subsidy, $173.3 \%$ with the thinning subsidy, and $181.5 \%$ with both subsidies. Thus, the estimated availability with both subsidies met the demand sufficiently in this region.
\end{abstract}

Keywords: feed-in tariff; harvesting system; subsidy; timber trade; woody biomass power plant

\section{Introduction}

To promote sustainable timber and forest biomass utilization, technically feasible and economically viable availability should be estimated considering forest regenerations. Yamamoto et al. [1] extracted production forests and estimated the annual availability of forest biomass resources under profitable forest management of private and communal forests as well as for national forests in the Tochigi Prefecture, Japan. Production forests were extracted as subcompartments where expected revenues surpassed all costs, from planting to final harvest, based on a 55-year rotation. Battuvshin et al. [2] expanded the estimates by including three prefectures (Fukushima, Ibaraki, and Gunma) that surround Tochigi, and considered the inter-prefectural trade. Fukushima belongs to the Tohoku region whereas Ibaraki, Tochigi, and Gunma belong to the Kanto region in Japan. 
The present study estimated the supply potential and availability of forest biomass resources of cedar, cypress, pine, and larch for woody biomass power generation in Aomori, Iwate, Miyagi, Akita, and Yamagata prefectures north, neighboring Fukushima in the Tohoku region.

\section{Materials and Methods}

The data used in this study include forest registration (tree species and site index) and GIS data (information on roads and subcompartment layers) from the prefectures for private and communal forests. Additionally, this study includes GIS data (subcompartment layers, including tree species) from the Forestry Agency of Japan for national forests as well as 10-m-grid digital elevation models (DEMs) from the Geographical Survey Institute.

Specifically, production forests were extracted and annual availability of timber and forest biomass resources was estimated in the following order: (1) estimation of supply potential and revenue of timber and forest biomass resources from thinning and final felling operations; (2) estimation of total expenses from planting to final felling operations; (3) estimation of economic balances during rotation ages; (4) extraction of profitable subcompartments as production forests; and (5) estimation of availability of timber and forest biomass resources on the basis of supply potential from profitable subcompartments. Then, annual availability was estimated by dividing the availability by each rotation period. Full technical details on the data analysis methods can be found in earlier papers $[1,2]$.

\section{Results and Discussions}

The annual supply potentials of timber and forest biomass resources were estimated at $11,388,960 \mathrm{~m}^{3} /$ year and $2,277,792 \mathrm{~m}^{3} /$ year, respectively. After forest operation systems were determined according to topography and harvesting costs were estimated, the annual availability of timber and forest biomass resources was estimated at 1,631,624 $\mathrm{m}^{3} /$ year and $326,325 \mathrm{~m}^{3} /$ year, respectively. Therefore, the ratio of availability to supply potential was $14.3 \%$. The ratio of Miyagi is the highest because of low harvesting costs with ground-based systems. On the other hand, the rates of Akita and Yamagata were low because of low timber prices and high regeneration costs with heavy snow. By applying the subsidy, the rates of availability to supply potential increased to $26.8 \%$ with the additional subsidy, $72.5 \%$ with the thinning subsidy, and $76.0 \%$ with both subsidies. The ratio of Akita was still low because of low timber prices. The demand was estimated at 953,340 $\mathrm{m}^{3} /$ year from $100,000 \mathrm{~m}^{3} /$ year with the generation capacity of $5 \mathrm{MW}$. The rate of forest biomass availability to the demand was $34.2 \%$. The rates were also increased to $64.1 \%$ with the additional regeneration subsidy, $173.3 \%$ with the thinning subsidy, and $181.5 \%$ with both subsidies. Thus, the estimated availability with both subsidies met the demand sufficiently in this region.

Since the actual timber production of the five prefectures was 4,667,000 $\mathrm{m}^{3} /$ year in 2018, the estimated annual availability of timber with the thinning subsidy, 8,258,304 $\mathrm{m}^{3} /$ year, was almost double that of the actual timber production. The estimated annual availability of forest biomass resources with the thinning subsidy, 1,651,845 $\mathrm{m}^{3} /$ year, was also almost double that of the actual usage in 2018 , which was $889,601 \mathrm{~m}^{3} / \mathrm{year}$. This was because the subsidy was applied to all stands in the estimations although the subsidy budget was limited. Therefore, estimations should be conducted while considering limited budgets. For example, Moriguchi et al. [3] determined subsidized forest stands to satisfy the required annual wood yield with minimum governmental expenses.

\section{Conclusions}

This study estimated the technically feasible and economically viable availability considering forest regenerations for five prefectures, namely Aomori, Iwate, Miyagi, 
Akita, and Yamagata. In order to estimate harvesting costs, harvesting systems were determined according to topography. The estimated availability with thinning and additional regeneration subsidies met the demand sufficiently in this region. Thus, subsidies play an important role in the profitability of forestry operations as well as the supply of timber and forest biomass resources in Japan. This study modeled trades between prefectures of the Tohoku region. Future study will expand the model to the whole of Japan.

Author Contributions: Conceptualization, K.A.; methodology, Y.M. and H.S.; software, Y.M. and H.S.; validation, Y.M. and K.A.; formal analysis, Y.M. and K.A.; investigation, Y.M. and K.A.; resources, U.H.; data curation, U.H.; writing-original draft preparation, Y.M.; writing-review and editing, K.A.; visualization, Y.M.; supervision, K.A.; project administration, K.A.; funding acquisition, K.A. All authors have read and agreed to the published version of the manuscript.

Funding: This study was supported by JSPS KAKENHI grant numbers 15H04508, 16KK0168 and $17 \mathrm{~K} 12849$.

Data Availability Statement: Restrictions apply to the availability of these data. Data was obtained from Aomori, Iwate, Miyagi, Akita, and Yamagata as well as the Forestry Agency of Japan and are available with the permission of Aomori, Iwate, Miyagi, Akita, and Yamagata as well as the Forestry Agency of Japan.

Acknowledgments: We are grateful to Aomori, Iwate, Miyagi, Akita, and Yamagata as well as the Forestry Agency of Japan for providing GIS data.

Conflicts of Interest: The authors declare no conflict of interest. The funders had no role in the design of the study; in the collection, analyses, or interpretation of data; in the writing of the manuscript, or in the decision to publish the results.

\section{References}

1. Yamamoto, T.; Aruga, K.; Shirasawa, H. Availability for small-scale woody biomass power generation from the view of forest resources in Tochigi prefecture, Japan. Int. J. For. Eng. 2019, 30, 210-217.

2. Battuvshin, B.; Matsuoka, Y.; Shirasawa, H.; Toyama, K.; Hayashi, U.; Aruga, K. Supply potential and annual availability of timber and forest biomass resources for energy considering inter-prefectural trade in Japan. Land Use Policy 2020, $97,104780$.

3. Moriguchi, K.; Ueki, T.; Saito, M. Determining subsidized forest stands to satisfy required annual wood yield with minimum governmental expense. Land Use Policy 2017, 67, 573-583. 